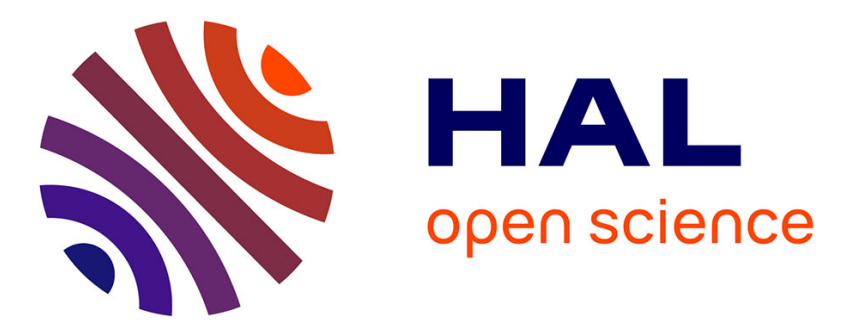

\title{
Non-invasive assessment of oxidative stress in preterm infants
}

\author{
Carmen Peña-Bautista, Thierry Durand, Claire Vigor, Camille Oger, \\ Jean-Marie Galano, Consuelo Cháfer-Pericás
}

\section{To cite this version:}

Carmen Peña-Bautista, Thierry Durand, Claire Vigor, Camille Oger, Jean-Marie Galano, et al.. Noninvasive assessment of oxidative stress in preterm infants. Free Radical Biology and Medicine, 2019, 142, pp.73-81. 10.1016/j.freeradbiomed.2019.02.019 . hal-02617362

\section{HAL Id: hal-02617362 \\ https://hal.science/hal-02617362}

Submitted on 2 Jun 2021

HAL is a multi-disciplinary open access archive for the deposit and dissemination of scientific research documents, whether they are published or not. The documents may come from teaching and research institutions in France or abroad, or from public or private research centers.
L'archive ouverte pluridisciplinaire HAL, est destinée au dépôt et à la diffusion de documents scientifiques de niveau recherche, publiés ou non, émanant des établissements d'enseignement et de recherche français ou étrangers, des laboratoires publics ou privés. 


\title{
Non-invasive assessment of oxidative stress in preterm infants
}

\author{
Carmen Peña-Bautista ${ }^{\mathrm{a}}$, Thierry Durand ${ }^{\mathrm{b}}$, Claire Vigor ${ }^{\mathrm{b}}$, Camille Oger $^{\mathrm{b}}$, Jean-Marie Galano ${ }^{\mathrm{b}}$, \\ Consuelo Cháfer-Pericás ${ }^{\mathrm{a}, *}$
}

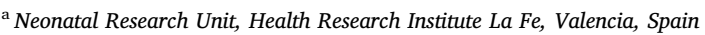

${ }^{\mathrm{b}}$ Institut des Biomolécules Max Mousseron, IBMM, University of Montpellier, CNRS ENSCM, Montpellier, France

A R T I C L E I N F O

\section{Keywords:}

Biomarker

Oxidative stress

Prematurity

Urine

SalivaKeywords:

Preterm infant

Saliva

Oxidative stress

Urine

Diagnostic techniques and procedures

\begin{abstract}
A B S T R A C T
Preterm newborns have an immature antioxidant defense system and are especially susceptible to oxidative stress. Resuscitation, mechanical ventilation, intermittent hypoxia and apneic episodes require frequently oxygen supplementation which leads to oxidative stress in preterm newborns. The consequences of oxidative damage are increased short and long-term morbidities, neurodevelopmental impairment and increased mortality.

Oxidative stress biomarkers are determined in blood samples from preterm children during their stay in neonatal intensive care units especially for research purposes. However, there is a tendency towards reducing invasive and painful techniques in the NICU (Neonatal Intensive Care Unit) and avoiding excessive blood extractions procedures.

In this paper, it has been described some studies that employed non-invasive samples to determine oxidative stress biomarkers form preterm infants in order to perform a close monitoring biomarker with a significant greater predictive value. Among these methods we describe a previously developed and validated high-performance liquid chromatography tandem mass spectrometry method that allow to accurately determine the most reliable biomarkers in biofluids, which are non-invasively and painlessly obtained.
\end{abstract}

\section{Introduction}

\subsection{Oxidative stress in preterm infants}

Oxidative stress is most commonly triggered by reactive oxygen species (ROS) (e.g. hydroxyl radicals, superoxide anions, hydrogen peroxides) generated under certain physiologic conditions in the mitochondria and other cell organelles (peroxisomes, Golgi, endoplasmic reticulum). ROS are originated as a consequence of a normal leak amounting $2 \%$ of the electrons transported along the electron transport chain (ETC), and in the endoplasmic reticulum or nuclear and cell membranes, but there are also generated when the antioxidant system renders incapable of scavenge ROS in excess [1-3]. In addition, enzymes, such as NADPH oxidases are great generators of ROS and constitute one of the most important sources of hydrogen peroxide [1,3]. Free radicals are highly reactive chemical species that instantaneously interact with nearby existing biomolecules in the cell (proteins, lipids, DNA and others) producing oxidized derivatives [4-6]. Some of them, show high reactivity and may form adducts with proteins, as well as oxidize other biomolecules, altering specific molecular pathways [7] (see Fig. 1).

The main causes of oxidative stress in the newborn period are associated with oxygen administration [8], mechanical ventilation [9], intermittent hypoxia and apnea episodes [10], and asphyxia [11]. In general, the fetal-to-neonatal transition is characterized by intermittent hypoxia periods, involving over-production of oxidative substances and a disequilibrium in important cellular pathways, such as oxidation or inflammation biomolecules [12]. Preterm newborns have an immature antioxidant defense system and are, therefore, prone to oxidative damage. As a consequence, preterm infants will develop some conditions related to the production of free radicals with short-and-long-term consequences [13]. In this sense, recent research has focused on the impact of perinatal oxidative stress on the human brain development and its associated morbidities [14,15]. Moreover, these oxidative stress conditions are related to some chronic pathologies such as necrotizing enterocolitis (NEC) [16,17], bronchopulmonary dysplasia (BPD) [18-20], retinopathy of prematurity (ROP) [21], cardiac dysfunction [22], and acute kidney injury [23]. Therefore, oxidative stress monitoring and control would be highly desirable in the neonatal period to avoid its negative consequences and to improve outcomes of preterm

\footnotetext{
* Corresponding author. Health Research Institute La Fe, Avda de Fernando Abril Martorell, 106, 46026, Valencia, Spain.

E-mail address: m.consuelo.chafer@uv.es (C. Cháfer-Pericás).
} 


$\begin{array}{llll}\text { List of abbreviations } & \text { LO } & \text { Limited oxygen strategy } \\ & & \text { LP } & \text { Light protected } \\ \text { AA } & \text { Amino acids } & \text { MDA } & \text { Malondialdehyde } \\ \text { AGE } & \text { Advanced glycation end products } & \text { NEC } & \text { Necrotizing enterocolitis } \\ \text { AOPP } & \text { Advanced oxidation protein products } & \text { NeuroF } & \text { Neurofurans } \\ \text { AscOOH } & \text { Ascorbylperoxide } & \text { NeuroP } & \text { Neuroprostanes } \\ \text { BAP } & \text { Biological antioxidant capacity } & \text { NICU } & \text { Neonatal Intensive Care Unit } \\ \text { BPD } & \text { Bronchopulmonary dysplasia } & \text { NO } & \text { Nitric oxide } \\ \text { 2-dG } & \text { 2'-deoxyguanosine } & \text { NOx } & \text { Nitric oxide stable metabolites } \\ \text { EIA } & \text { Enzyme immunoassay } & \text { NPBI } & \text { Non-protein bound iron } \\ \text { ELISA } & \text { Enzyme-linked immunosorbent assay } & \text { 3-NT } & \text { 3-nitrotyrosine } \\ \text { ETC } & \text { Electron transport chain } & \text { MVP } & \text { Multivitamins } \\ \text { FM } & \text { Formula milk } & \text { 8-OHdG } & \text { 8-Oxo-2'deoxyguanosine } \\ \text { FRAP } & \text { Ferric reducing antioxidant power } & \text { O-Tyr } & \text { Ortho-tyrosine } \\ \text { GST } & \text { Glutathione S-transferase } & \text { PF } & \text { Preterm formula } \\ \text { GSH } & \text { Glutathione } & \text { PGE2 } & \text { Prostaglandin E2 } \\ \text { HCA } & \text { Histological corioamnionitis } & \text { Phe } & \text { Phenylalanine } \\ \text { HELL } & \text { Ne-(hexanoyl) lysine } & \text { PrCarb } & \text { Protein carbonyls } \\ \text { HM } & \text { Human milk } & \text { ROI } & \text { Reactive oxygen intermediates } \\ \text { HOX } & \text { High oxygen strategy } & \text { ROP } & \text { Retinopathy of prematurity } \\ \text { HPLC } & \text { High performance liquid chromatography } & \text { ROS } & \text { Reactive oxygen species } \\ \text { hsPDA } & \text { Significant hemodynamically patent ductus arteriosus } & \text { SOD } & \text { Superoxide dismutase } \\ \text { IL-6 } & \text { Interleukin 6 } & \text { TAC } & \text { Total antioxidant capacity } \\ \text { IsoF } & \text { Isofurans } & \text { TBARS } & \text { Thiobarbituric acid reactive substances } \\ \text { IsoP } & \text { Isoprostanes } & \text { TH } & \text { Total hydroperoxides } \\ \text { 8-isoPGF } & \text { 8-iso-prostaglandin F2 alpha } & \text { TXB2 } & \text { Tromboxane B2 } \\ \text { IVH } & \text { Intraventricular hemorrhage } & \text { VLBW } & \text { Very low birth weight } \\ \text { LBW } & \text { Low birthweight } & \text { VU } & \text { Vascular underperfusion } \\ \text { LE } & \text { Lipid emulsion } & & \\ & & & \end{array}$

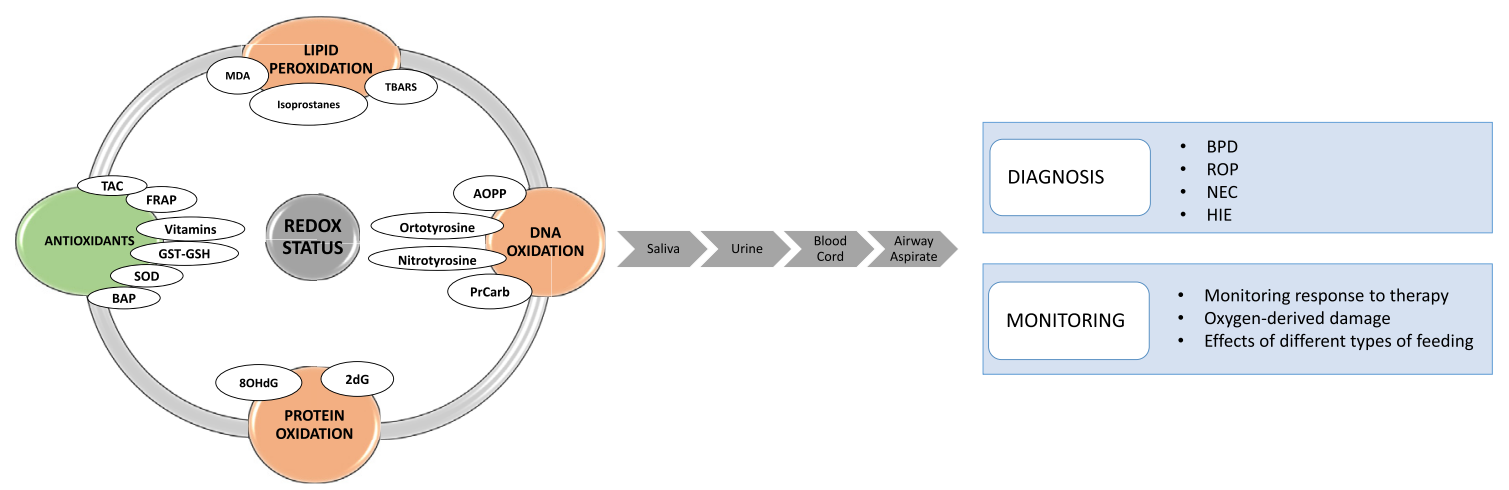

Fig. 1. Diagram representing the oxidative stress biomarkers determined in non-invasive biological samples.

children. In the last few years, some potential treatments that could reduce oxidative stress levels in preterm infants have been studied, such as melatonin or surfactant, but more clinical trials are required in order to confirm their clinical applicability [24].

\subsection{Oxidative stress assessment and management}

There is an increasing need in the development of reliable tools to evaluate, control, and reduce oxidative stress in preterm newborns [25]. A promising evaluation at molecular level is based on biomarkers obtained from biomolecules oxidation [26].

Biomarkers derived from lipids peroxidation play an important role in brain damage assessment, since brain is characterized by high lipid composition and oxygen consumption. Among these compounds, malondialdehyde (MDA) has been the most studied, and it has been determined in plasma and bronchoalveolar lavage samples from preterm newborns [27-29], using the thiobarbituric acid reactive substances (TBARS) assay. Thus, high levels of TBARS were found in studies carried out with neonatal blood samples a few days after birth [30]. However, most of the TBARS formed in vivo are not related to lipid oxidation [31]. In addition, plasma and serum isoprostanes offer a reliable measurement of in vivo oxidative stress [32,33], and constitute biomarkers that are increasingly used. Regarding DNA and protein oxidation biomarkers, 8-hydroxy-2'-deoxyguanosine (8-OHdG) and carbonyl proteins have been the most studied compounds, respectively [34]. In this sense, 8-OHdG is used as oxidative stress biomarker from blood and tracheal aspirates samples [35,36]. Also, some protein oxidation products, such as carbonylated proteins, are evaluated as oxidative stress biomarkers from plasma and bronchoalveolar lavage fluid samples [37,38].

In general, most of the studies have evaluated oxidative stress in blood samples, and a few of them used tracheal aspirates and bronchoalveolar lavage fluid samples. However, the invasiveness and pain derived from these sampling procedures limit their sequential use for monitoring evolving conditions.

Therefore, non-invasively obtained samples could allow to monitor 


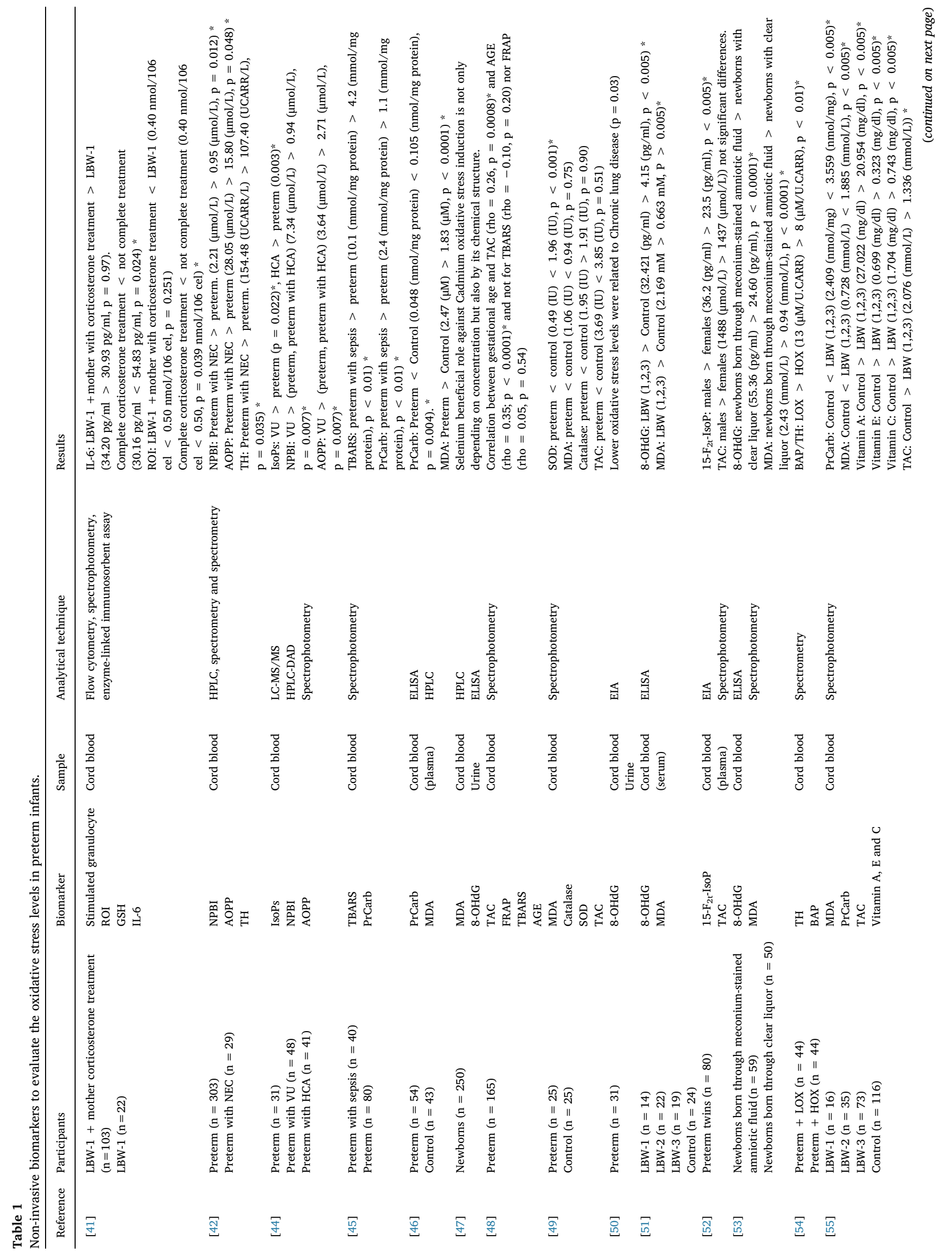




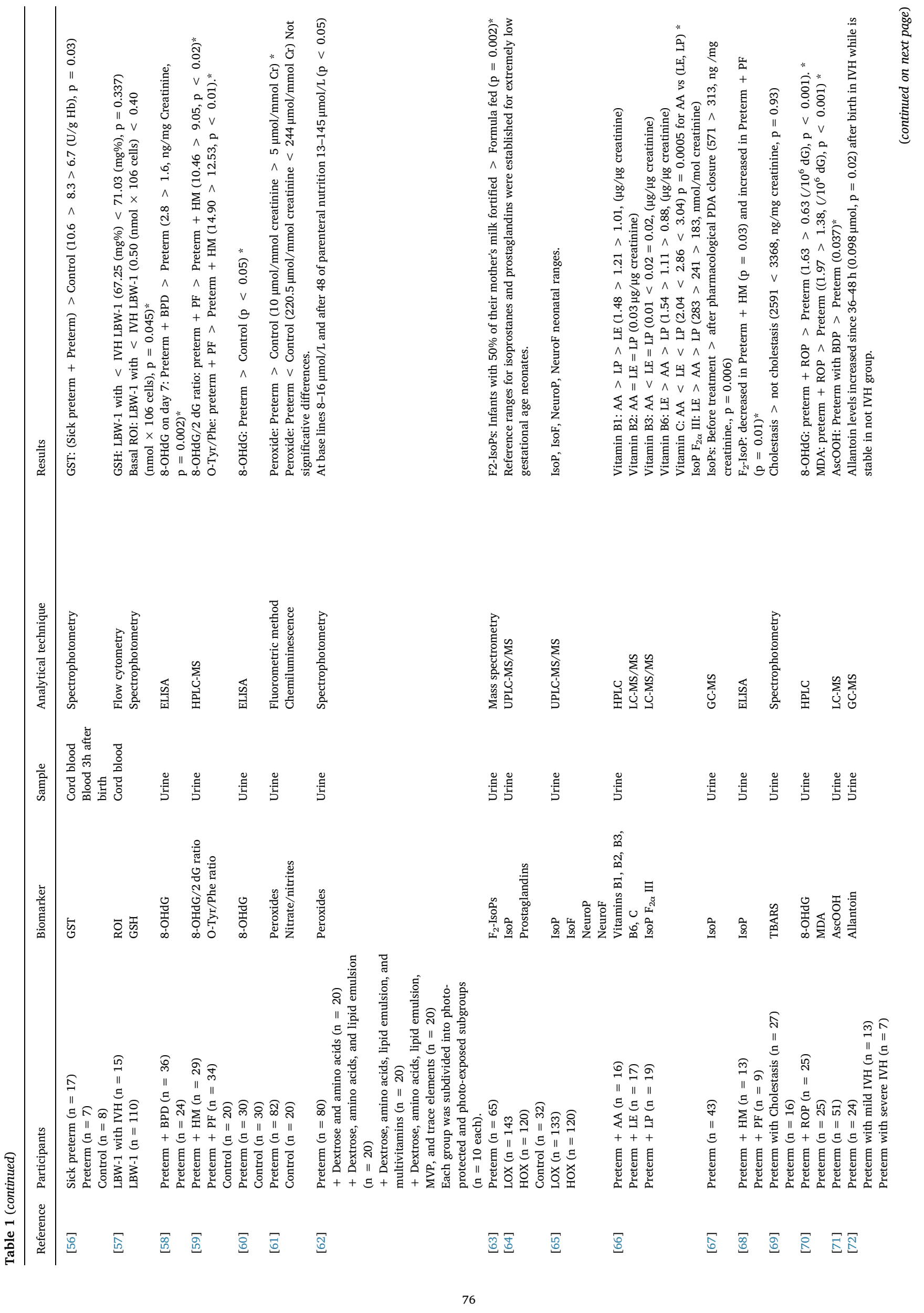




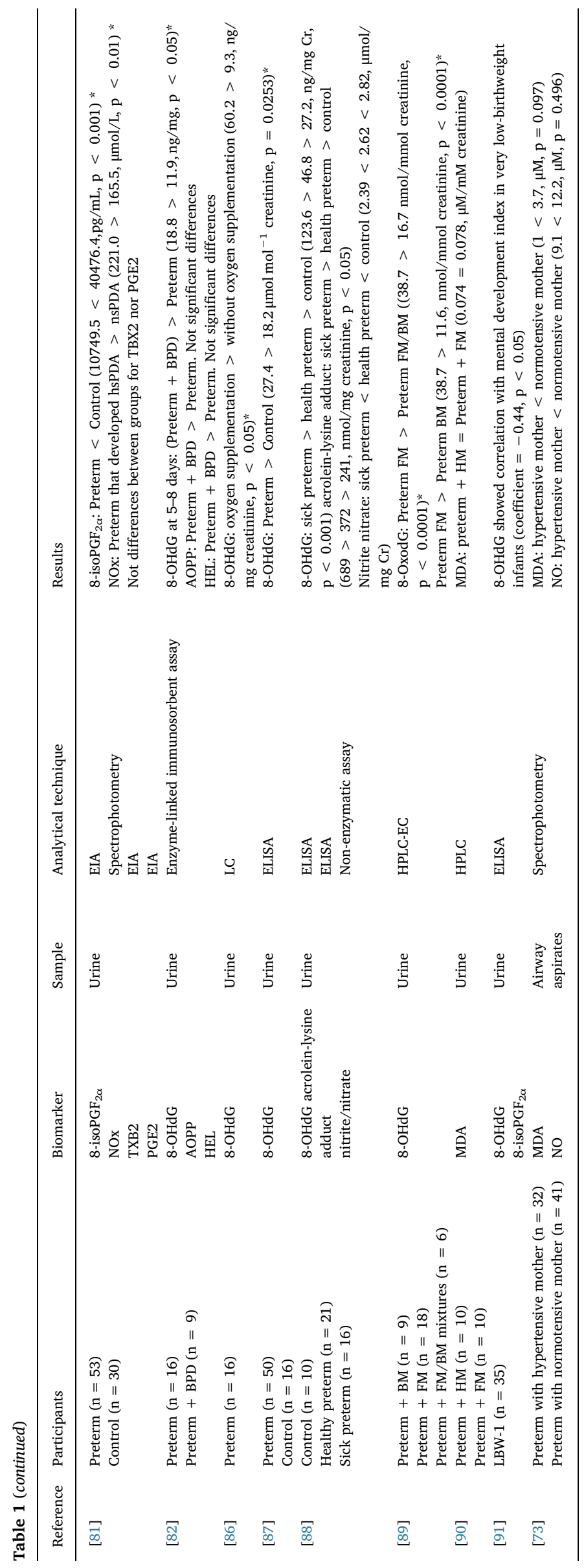


levels of biomarkers with desired frequency, without causing pain or distress to the infants and thus, providing clinicians with very relevant information [39]. In addition, the antioxidant profile evaluation would allow a personalized treatment avoiding oxidative stress related pathologies [40].

The aim of this article is to review oxidative stress biomarkers determined in non-invasive samples as oxidative status evaluation in preterm infants, which could be used as diagnosis, prognosis and monitorization of different treatments.

\section{Non-invasive monitoring of oxidative stress in preterm newborns}

In Table 1 we have summarized some studies that have determined oxidative stress biomarkers in non-invasively obtained samples from preterm infants.

\subsection{Biomarkers in cord blood samples}

Cord blood has been the most widely employed matrix in the evaluation of several mechanisms related to prematurity [41-57]. Among these studies, 8-OHdG, MDA, and protein carbonyls are the most used biomarkers, and they reflect DNA, lipid and protein oxidation, respectively $[43,46,47,49-51,53,55]$. Significant differences were observed for these biomarkers between preterm and term newborns showing higher levels of carbonylated proteins in preterm than in term infants (99.8 and $82.9 \mathrm{pmol} \mathrm{mg}^{-1}$, respectively) [43]. In addition, different antioxidant compounds, such as vitamins, biological antioxidant potential or glutathione $S$ transferase, have also been measured in cord blood samples, since their low levels favor the oxidative stress [48,52,54-57]. In fact, the ratio between biological antioxidant potential and total hydroperoxide (BAP/TH) showed correlation with the oxygen supplementation received by preterm newborns [54], and the preterm newborns showed correlation with gestational age at birth for total antioxidant capacity (TAC) and advanced glycation products (AGE) [48]. Despite the usefulness of cord blood samples to evaluate the oxidative stress during birth and its potential consequences in newborns, it is not useful to perform follow-up studies along some weeks/months after birth because new samples are needed in order to monitor changes along time. However, it could be useful in the prognosis of some pathologies such as NEC and sepsis [42,45].

\subsection{Biomarkers in urine samples}

Urine has rendered highly efficacious as non-invasively obtained biofluid. Some of the potential biomarkers in this matrix show usefulness in the prediction, monitoring or evaluation of the risk of suffering from different pathologies associated to oxidative stress. According to this, high peroxides and 8-OHdG levels were found in preterm infants [58-60], specifically higher peroxides levels were found in preterm with BPD than in preterm newborns without the pathology [58]. Also, levels of these biomarkers were higher in preterm that received parenteral nutrition, as well as in preterm compared to term infants $[61,62]$. Other biomarkers related to lipid peroxidation that have been determined in urine samples are isoprostanes [63-68], TBARS [69] and MDA [70]. Regarding isoprostanes, their determination is useful for ductus arteriosus ibuprofen treatment monitoring since their levels usually decrease after the treatment [67], as well as in the study of the beneficial effects of human milk since these newborns show lower levels than those fed with preterm formula $[63,68]$. In addition, the normality ranges of different isoprostanes families were established in randomized, controlled, and blinded clinical trials from preterm infants [65]. However, TBARS seem not to be useful in the diagnosis of cholestasis, showing similar values between preterm infants with and without the pathology [69]. Another study found that 8-OHdG, isoprostanes, and ascorbyl peroxide were useful biomarkers to evaluate
BPD risk in very low weight infants, a group susceptible to suffer this pathology [58,71]. In other studies, 8-OHdG and MDA were considered potential biomarkers of ROP [70], and allantoin was used to evaluate the risk for intraventricular hemorrhage in preterm newborns [72]. BPD was also monitored by means of the evaluation of MDA and NO levels in airway aspirates [73].

\subsection{Biomarkers in saliva samples}

Saliva is a promising matrix to evaluate oxidative stress in preterm newborns. Saliva sampling is easy, and it has shown applicability in different studies [74]. Hence, saliva has been used to measure melatonin levels in preterm newborns, being able to replace its determination in plasma samples [75].

\section{Analytical methods development and applications}

Most of the analytical methods applied to determine oxidative stress biomarkers in non-invasive samples are based on immunoassays, colorimetric assays, commercial kits and spectrophotometric measures (Table 1). These techniques show some disadvantages, such as, low sensitivity and specificity, high number of interferences and matrix effect, and low precision.

Recently, our group has validated reliable analytical methods to determine cortisol and isoprostanoids in non-invasive samples, such as saliva $[76,77]$. They are based on high-performance liquid chromatography coupled to tandem mass spectrometry (HPLC-MS/MS) and they are useful in the determination of 18 lipid peroxidation products, showing the advantages of high selectivity and sensitivity. These methods showed satisfactory limits of detection and quantification allowing the reliable determination of these compounds in saliva samples and reflecting oxidative stress damage. They have shown utility as potential biomarkers of neurodegenerative diseases, and currently they are being applied to the study of oxidative stress in ex-preterm infants, as well as to evaluate the lipid peroxidation in infants with autism spectrum disorders [77]. In addition, our group developed a new analytical method based on Surface-enhanced Raman spectroscopy to determine GSH in blood samples showing its capacity to obtain reproducible results in small sample volumes [78]. In fact, this method was applied to newborn cord blood samples showing results transferable to clinical practice for the oxidative stress study [79].

It is important to highlight that saliva samples have not been commonly used in the evaluation of oxidative stress damage in preterm newborns and this is a field that should continue growing. This easy sampling will allow the oxidative stress monitoring in this group of susceptible patients avoiding any additional pain.

\subsection{Limitations of the analytical methods}

Some of the developed methods that are used for research using non-invasive samples in preterm infants are based on mass spectrometry determinations $[39,41,43,44,56,62,69]$. However, these analytical methods are not suitable in the clinical practice since they are expensive and require specialized technician personnel. In this sense, it is important to develop more simple analytical methods to determine these biomarkers in non-invasive samples with suitable sensitivity and reproducibility in order to be clinically applied.

In addition, other studies used methods such as ELISA or spectrophotometry $[45,46,48,50-52,55,57,66]$. They are easily applicable to clinical practice but still need to be validated clinically, and their pathological values should be well established for the different diseases as potential biomarkers.

\section{Oxidative stress monitoring proposal in the neonatal period}

Non-invasive monitoring of oxidative stress damage in preterm 
newborns could be reliably performed with salivary and urinary determinations of different oxidized products. Brain is one of the most important organs affected by oxidative stress in preterm newborns, and considering its high lipid composition, the determination of lipid peroxidation biomarkers in saliva or urine samples could be highly specific of neurological damage [80]. In this sense, it is important to highlight the determination of isoprostanes/neuroprostanes/dihomo-isoprostanes inasmuch as these compounds would reflect the in vivo oxidation of arachidonic, docosahexanoic and adrenic acid, respectively. Among these lipid peroxidation compounds, 8-isoPGF $2 \alpha$ levels in urine have been related to gestational age at birth [81], and, in general, they were considered useful markers of the oxidative stress status derived from feeding type during early life in premature infants [63,68]. A second important group of pathologies in these patients are those related to the respiratory system, such as BPD. For this, the determination of 8-OHdG in urine has shown good results being able to differentiate between healthy preterm and those with BDP [58]. In fact, Joung et al. found 8-OHdG levels of 2.8 and $1.6 \mathrm{ng} \mathrm{mg}^{-1}$ creatinine, in healthy and BPD preterm infants, respectively, while Tokuriki obtained 18.8 and $11.9 \mathrm{ng} \mathrm{mg}^{-1}$ creatinine in similar participants' groups. In both cases statistically significant differences were observed [58,82]. Nevertheless, isofurans are the main validated biomarkers for chronic lung diseases and BPD prediction as it was shown by Vento et al. [83], and Kuligowski el al [65]. Also, airway aspirates could reflect respiratory system damage associated to BPD through the study of the microbiome in these samples, although this field would need further research to corroborate its utility and other biomarkers reflecting oxidative damage should be studied [84]. Until now, tracheal aspirates have been used and they could reflect oxidative damage caused by macrophages as an unspecific response to oxygen, inflammation and infection. In this regard, biomarkers such as 3-chloro-tyrosine and glutathione sulfonamide have been successfully employed since they show elevated levels in newborns who suffered from chronic disease $\left(88 \mu \mathrm{mol} \mathrm{mol}^{-1}\right.$ tyrosine) compared to healthy newborns $\left(49 \mu \mathrm{mol} \mathrm{mol}^{-1}\right.$ tyrosine) [85]. For ocular problems in preterm newborns such as ROP, analysis of tears could constitute a promising matrix for oxidative stress evaluation; however, no published experience for this purpose is available. Monitorization of processes such as ibuprofen treatment of patent ductus arteriosus has been carried out using serial isoprostanes determinations [67].

We conclude that for monitoring oxidative stress and associated damage in preterm newborns, urine could be a useful matrix in which lipid peroxidation, oxidized proteins and nucleic acid biomarkers could be easily and sequentially determined. Also, saliva and airway aspirates seem to be promising matrices for oxidative stress biomarkers determination that need to be validated before applying to research studies and clinical practice.

\section{Conflicts of interest}

The authors report no conflict of interest.

\section{Acknowledgements}

CC-P acknowledges a post-doctoral "Miguel Servet I" Grant (CP16/ 00082) from the Health Research Institute Carlos III (Spanish Ministry of Economy and Competitiveness).

CP-B acknowledges a pre-doctoral Grant (associated to "Miguel Servet" project CP16/00082) from the Health Research Institute Carlos III (Spanish Ministry of Economy, Industry and Competitiveness).

\section{References}

[1] M. Schieber, N.S. Chandel, ROS function in redox signaling and oxidative stress, Curr. Biol. 24 (2014) R453-R462, https://doi.org/10.1016/j.cub.2014.03.034.

[2] H. Sies, Oxidative stress: a concept in redox biology and medicine, Redox Biol 4
(2015) 180-183, https://doi.org/10.1016/j.redox.2015.01.002.

[3] V.I. Lushchak, Free radicals, reactive oxygen species, oxidative stress and its classification, Chem. Biol. Interact. 224 (2014) 164-175, https://doi.org/10.1016/j. cbi.2014.10.016.

[4] M. Fedorova, R.C. Bollineni, R. Hoffmann, Protein carbonylation as a major hallmark of oxidative damage: update of analytical strategies, Mass Spectrom. 33 (2014) 79-97, https://doi.org/10.1002/mas.21381.

[5] A. Ayala, M.F. Muñoz, S. Argüelles, Lipid peroxidation: production, metabolism, and signaling mechanisms of malondialdehyde and 4-hydroxy-2-nonenal, Oxid. Med. Cell. Longev. 2014 (2014) 360438, https://doi.org/10.1155/2014/360438.

[6] O. Zitka, S. Krizkova, S. Skalickova, P. Kopel, P. Babula, V. Adam, R. Kizek, Electrochemical study of DNA damaged by oxidation stress, Comb. Chem. High Throughput Screen. 16 (2013) 130-141.

[7] S. Grimm S, A. Höhn, T. Grune, Oxidative protein damage and the proteasome, Amino Acids 42 (2012) 23-38, https://doi.org/10.1007/s00726-010-0646-8.

[8] M.L. Tataranno, J.L. Oei, S. Perrone, I.M. Wright, J.P. Smyth, K. Lui, W.O. TarnowMordi, M. Longini, F. Proietti, S. Negro, O.D. Saugstad, G. Buonocore, Resuscitating preterm infants with $100 \%$ oxygen is associated with higher oxidative stress than room air, Acta Paediatr. 104 (2015) 759-765, https://doi.org/10.1111/apa.13039.

[9] T.A. Moore, K.K. Schmid, A. Anderson-Berry, A.M. Berger, Lung disease, oxidative stress, and oxygen requirements in preterm infants, Biol. Res. Nurs. 18 (2016) 322-330, https://doi.org/10.1177/1099800415611746.

[10] K.D. Beharry, C.L. Cai, G.B. Valencia, A.M. Valencia, D.R. Lazzaro, F. BanyMohammed, J.V. Aranda, Neonatal intermittent hypoxia, reactive oxygen species, and oxygen-induced retinopathy, React. Oxyg. Species (Apex) 3 (2017) 12-25, https://doi.org/10.20455/ros.2017.805.

[11] I. Labadaridis, M. Moraitou, M. Theodoraki, E. Dimitriou, J. Sarafidou, $\mathrm{H}$. Michelakakis, Linoleic and arachidonic acid in perinatal asphyxia and prematurity, J. Matern. Fetal Neonatal Med. 20 (2007) 623-626, https://doi.org/10. 1080/14767050701449745.

[12] P.D. Ray, B.W. Huang, Y. Tsuji, Reactive oxygen species (ROS) homeostasis and redox regulation in cellular signalling, Cell. Signal. 24 (2012) 981-990, https://doi. org/10.1016/j.cellsig.2012.01.008.

[13] J.M. Davis, R.L. Auten, Maturation of the antioxidant system and the effects on preterm birth, Semin. Fetal Neonatal Med. 15 (2010) 191-195, https://doi.org/10. 1016/j.siny.2010.04.001.

[14] S. Perrone, L.M. Tataranno, G. Stazzoni, L. Ramenghi, G. Buonocore, Brain susceptibility to oxidative stress in the perinatal period, J. Matern. Fetal Neonatal Med. 28 (Suppl 1) (2015) 2291-2295, https://doi.org/10.3109/14767058.2013.796170.

[15] B. Vasiljević, S. Maglajlić-Djukić, M. Gojnić, S. Stanković, The role of oxidative stress in perinatal hypoxic-ischemic brain injury, Srp. Arh. Celok. Lek. 140 (2012) 35-41.

[16] S. Perrone, M.L. Tataranno, A. Santacroce, S. Negro, G. Buonocore, The role of oxidative stress on necrotizing enterocolitis in very low birth weight infants, Curr. Pediatr. Rev. 10 (2014) 202-207.

[17] A. Aceti, I. Beghetti, S. Martini, G. Faldella, L. Corvaglia, Oxidative stress and necrotizing enterocolitis: pathogenetic mechanisms, opportunities for intervention, and role of human milk, Oxid. Med. Cell Longev. 2018 (2018) 7397659, https://doi. org/10.1155/2018/7397659.

[18] F. Holguin, Oxidative stress in airway diseases, Ann. Am. Thorac. Soc. 10 (Suppl) (2013) S150-S157, https://doi.org/10.1513/AnnalsATS.201305 116AW.

[19] T.A. Moore, K.K. Schmid, A. Anderson-Berry, A.M. Berger, Lung disease, oxidative stress, and oxygen requirements in preterm infants, Biol. Res. Nurs. 18 (2016) 322-330, https://doi.org/10.1177/1099800415611746.

[20] S. Perrone, M.L. Tataranno, G. Buonocore, Oxidative stress and bronchopulmonary dysplasia, J. Clin. Neonatol. 1 (2012) 109-114, https://doi.org/10.4103/22494847.101683.

[21] H. Wang, S.X. Zhang, M.E. Hartnett, Signaling pathways triggered by oxidative stress that mediate features of severe retinopathy of prematurity, JAMA Ophthalmol 131 (2013) 80-85, https://doi.org/10.1001/jamaophthalmol.2013. 986.

[22] M. Bertagnolli, F. Huyard, A. Cloutier, Z. Anstey, J.É. Huot-Marchand, C. Fallaha, P. Paradis, E.L. Schiffrin, D. Deblois, A.M. Nuyt, Transient neonatal high oxygen exposure leads to early adult cardiac dysfunction, remodeling, and activation of the renin-angiotensin system, Hypertension 63 (2014) 143-150, https://doi.org/10. 1161/HYPERTENSIONAHA.113.01760.

[23] J. Ivanišević, J. Kotur-Stevuljević, A. Stefanović, M. Miljković, Z. Jelić-Ivanović, B. Pejović, A. Peco-Antić, Association of paraoxonase 1 and oxidative stress with acute kidney injury in premature asphyxiated neonates, Chem. Biol. Interact. 272 (2017) 47-52, https://doi.org/10.1016/j.cbi.2017.04.014.

[24] C. Poggi, C. Dani, Antioxidant strategies and respiratory disease of the preterm newborn: an update, Oxid. Med. Cell. Longev. 2014 (2014) 721043.

[25] M. Inayat, F. Bany-Mohammed, A. Valencia, C. Tay, J. Jacinto, J.V. Aranda, K.D. Beharry, Antioxidants and biomarkers of oxidative stress in preterm infants with symptomatic patent ductus arteriosus, Am. J. Perinatol. 32 (2015) 895-904, https://doi.org/10.1055/s-0035-1544948.

[26] S. Perrone, M.L. Tataranno, G. Stazzoni, G. Buonocore, Biomarkers of oxidative stress in fetal and neonatal diseases, J. Matern. Fetal Neonatal Med. 25 (2012) 2575-2578, https://doi.org/10.3109/14767058.2012.718004.

[27] L. Slater, Y. Asmerom, D.S. Boskovic, K. Bahjri, M.S. Plank, K.R. Angeles, R. Phillips, D. Deming, S. Ashwal, K. Hougland, E. Fayard, D.M. Angeles, Procedural pain and oxidative stress in premature neonates, J. Pain 13 (2012) 590-597, https://doi.org/ 10.1016/j.jpain.2012.03.010.

[28] R.W. Cooke, J.A. Drury, Reduction of oxidative stress marker in lung fluid of preterm infants after administration of intra-tracheal liposomal glutathione, Biol. Neonate 87 (2005) 178-180. 
[29] K.J. Collard, S. Godeck, J.E. Holley, Blood transfusion and pulmonary lipid peroxidation in ventilated premature babies, Pediatr. Pulmonol. 39 (2005) 257-261.

[30] M. Wilinska, M.K. Borszewska-Kornacka, T. Niemiec, G. Jakiel, Oxidative stress and total antioxidant status in term newborns and their mothers, Ann. Agric. Environ. Med. 22 (2015) 736-740, https://doi.org/10.5604/12321966.1185786.

[31] B. Halliwell, M. Whiteman, Measuring reactive species and oxidative damage in vivo and in cell culture: how should you do it and what do the results mean? Br. J. Pharmacol. 142 (2004) 231-255.

[32] C. Cháfer-Pericás, I. Torres-Cuevas, A. Sanchez-Illana, J. Escobar, J. Kuligowski, R. Solberg, H.T. Garberg, M.U. Huun, O.D. Saugstad, M. Vento, Development of a reliable analytical method to determine lipid peroxidation biomarkers in newborn plasma samples, Talanta 153 (2016) 152-157, https://doi.org/10.1016/j.talanta. 2016.03.010.

[33] C. Cháfer-Pericás, L. Rahkonen, A. Sánchez-Illana, J. Kuligowski, I. Torres-Cuevas, M. Cernada, E. Cubells, A. Nuñez-Ramiro, S. Andersson, M. Vento, J. Escobar, Ultra high performance liquid chromatography coupled to tandem mass spectrometry determination of lipid peroxidation biomarkers in newborn serum samples, Anal. Chim. Acta 886 (2015) 214-220, https://doi.org/10.1016/j.aca.2015.06.028.

[34] J. Frijhoff, P.G. Winyard, N. Zarkovic, S.S. Davies, R. Stocker, D. Cheng, A.R. Knight, E.L. Taylor, J. Oettrich, T. Ruskovska, A.C. Gasparovic, A. Cuadrado, D. Weber, H.E. Poulsen, T. Grune, H.H. Schmidt, P. Ghezzi, Clinical relevance of biomarkers of oxidative stress, Antioxidants Redox Signal. 23 (2015) 1144-1170.

[35] O. Ates, H.H. Alp, I. Caner, A. Yildirim, A. Tastekin, I. Kocer, O. Baykal, Oxidative DNA damage in retinopathy of prematurity, Eur. J. Ophthalmol. 19 (2009) 80-85.

[36] C.C. Hsiao, J.C. Chang, L.Y. Tsao, R.C. Yang, H.N. Chen, C.H. Lee, C.Y. Lin, Y.G. Tsai, Correlates of elevated interleukin-6 and 8-hydroxy-2'-deoxyguanosine levels in tracheal aspirates from very low birth weight infants who develop bronchopulmonary dysplasia, Pediatr. Neonatol. 58 (2017) 63-69, https://doi.org/ 10.1016/j.pedneo.2016.01.004.

[37] C.C. Winterbourn, T. Chan, I.H. Buss, T.E. Inder, N. Mogridge, B.A. Darlow, Protein carbonyls and lipid peroxidation products as oxidation markers in preterm infant plasma: associations with chronic lung disease and retinopathy and effects of selenium supplementation, Pediatr. Res. 48 (2000) 84-90.

[38] B.C. Schock, D.G. Sweet, H.L. Halliday, I.S. Young, M. Ennis, Oxidative stress in lavage fluid of preterm infants at risk of chronic lung disease, Am. J. Physiol. Lung Cell Mol. Physiol. 281 (2001) L1386-L1391.

[39] L. Slater, Y. Asmerom, D.S. Boskovic, K. Bahjri, M.S. Plank, K.R. Angeles, R. Phillips, D. Deming, S. Ashwal, K. Hougland, E. Fayard, D.M. Angeles, Procedural pain and oxidative stress in premature neonates, J. Pain 13 (2012) 590-597, https://doi.org/ 10.1016/j.jpain.2012.03.010

[40] N.V. Margaritelis, V. Paschalis, A.A. Theodorou, A. Kyparos, M.G. Nikolaidis, Antioxidants in personalized nutrition and exercise, Adv. Nutr. 0 (2018) 1-11.

[41] J.P. Caldas, M.M. Vilela, C.A. Braghini, T.N. Mazzola, S.T. Marba, Antenatal maternal corticosteroid administration and markers of oxidative stress and inflammation in umbilical cord blood from very low birth weight preterm newborn infants, J. Pediatr. 88 (2012) 61-66, https://doi.org/10.2223/JPED.2158.

[42] S. Perrone, M.L. Tataranno, S. Negro, S. Cornacchione, M. Longini, F. Proietti, V. Soubasi, M.J. Benders, F. Van Bel, G. Buonocore, May oxidative stress biomarkers in cord blood predict the occurrence of necrotizing enterocolitis in preterm infants? J. Matern. Fetal Neonatal Med. 25 (Suppl 1) (2012) 128-131, https://doi.org/10. 3109/14767058.2012.663197.

[43] D. Weber, W. Stuetz, W. Bernhard, A. Franz, M. Raith, T. Grune, N. Breusing, Oxidative stress markers and micronutrients in maternal and cord blood in relation to neonatal outcome, Eur. J. Clin. Nutr. 68 (2014) 215-222, https://doi.org/10. 1038/ejcn.2013.263.

[44] S. Perrone, M.L. Tataranno, S. Negro, M. Longini, M.S. Toti, M.G. Alagna, F. Proietti, F. Bazzini, P. Toti, G. Buonocore, Placental histological examination and the relationship with oxidative stress in preterm infants, Placenta 46 (2016) 72-78, https://doi.org/10.1016/j.placenta.2016.08.084.

[45] A.C. Cancelier, F. Petronilho, A. Reinke, L. Constantino, R. Machado, C. Ritter, F. Dal-Pizzol, Inflammatory and oxidative parameters in cord blood as diagnostic of early-onset neonatal sepsis: a case-control study, Pediatr. Crit. Care Med. 10 (2009) 467-471, https://doi.org/10.1097/PCC.0b013e318198b0e3.

[46] T.J. Mocatta, C.C. Winterbourn, T.E. Inder, B.A. Darlow, The effect of gestational age and labour on markers of lipid and protein oxidation in cord plasma, Free Radic. Res. 38 (2004) 185-191.

[47] I. Al-Saleh, R. Al-Rouqi, C.A. Obsum, N. Shinwari, A. Mashhour, G. Billedo, Y. AlSarraj, A. Rabbah, Interaction between cadmium (Cd), selenium (Se) and oxidative stress biomarkers in healthy mothers and its impact on birth anthropometric measures, Int. J. Hyg Environ. Health 218 (2015) 66-90, https://doi.org/10.1016/ j.ijheh.2014.08.001.

[48] I. Musilova, L. Tothova, R. Menon, B. Vlkova, P. Celec, H. Hornychova, R. Kutova, C. Andrys, M. Stepan, M. Kacerovsky, Umbilical cord blood markers of oxidative stress in pregnancies complicated by preterm prelabor rupture of membranes, J. Matern. Fetal Neonatal Med. 29 (2016) 1900-1910, https://doi.org/10.3109/ 14767058.2015.1074997.

[49] M. Norishadkam, S. Andishmand, J. Zavar Reza, M.J. Zare Sakhvidi, V.R. Hachesoo, Oxidative stress and DNA damage in the cord blood of preterm infants, Mutat. Res. 824 (2017) 20-24, https://doi.org/10.1016/j.mrgentox.2017.10.003.

[50] T.A. Moore, K.K. Schmid, A. Anderson-Berry, A.M. Berger, Lung disease, oxidative stress, and oxygen requirements in preterm infants, Biol. Res. Nurs. 18 (2016) 322-330, https://doi.org/10.1177/1099800415611746.

[51] R. Negi, D. Pande, A. Kumar, R.S. Khanna, H.D. Khanna, In vivo oxidative DNA damage and lipid peroxidation as a biomarker of oxidative stress in preterm lowbirthweight infants, J. Trop. Pediatr. 58 (2012) 326-328, https://doi.org/10.1093/ tropej/fmr078.
[52] L. Minghetti, A. Greco, V. Zanardo, A. Suppiej, Early-life sex-dependent vulnerability to oxidative stress: the natural twining model, J. Matern. Fetal Neonatal Med. 26 (2013) 259-262, https://doi.org/10.3109/14767058.2012.733751.

[53] T. Bandyopadhyay, B.D. Bhatia, H.D. Khanna, A study of oxidative stress in neonates delivered through meconium-stained amniotic fluid, Eur. J. Pediatr. 176 (2017) 317-325, https://doi.org/10.1007/s00431-016-2845-0.

[54] V.S. Kapadia, L.F. Chalak, J.E. Sparks, J.R. Allen, R.C. Savani, M.H. Wyckoff, Resuscitation of preterm neonates with limited versus high oxygen strategy, Pediatrics 132 (2013) e1488-e1496, https://doi.org/10.1542/peds.2013-0978.

[55] R. Negi, D. Pande, A. Kumar, R.S. Khanna, H.D. Khanna, Evaluation of biomarkers of oxidative stress and antioxidant capacity in the cord blood of preterm low birth weight neonates, J. Matern. Fetal Neonatal Med. 25 (2012) 1338-1341, https://doi. org /10.3109/14767058.2011.633672.

[56] V.M. Neefjes, C.T. Evelo, L.G. Baars, C.E. Blanco, Erythrocyte glutathione S transferase as a marker of oxidative stress at birth, Arch. Dis. Child. Fetal Neonatal Ed. 81 (1999) F130-F133.

[57] J.P. Caldas, C.A. Braghini, T.N. Mazzola, M.M. Vilela, S.T. Marba, Peri-intraventricular hemorrhage and oxidative and inflammatory stress markers in verylow birth weight newborns, J. Pediatr. 91 (2015) 373-379, https://doi.org/10. 1016/j.jped.2014.09.008.

[58] K.E. Joung, H.S. Kim, J. Lee, G.H. Shim, C.W. Choi, E.K. Kim, B.I. Kim, J.H. Choi, Correlation of urinary inflammatory and oxidative stress markers in very low birth weight infants with subsequent development of bronchopulmonary dysplasia, Free Radic. Res. 45 (2011) 1024-1032, https://doi.org/10.3109/10715762.2011. 588229.

[59] A. Ledo, A. Arduini, M.A. Asensi, J. Sastre, R. Escrig, M. Brugada, M. Aguar, P. Saenz, M. Vento, Human milk enhances antioxidant defenses against hydroxyl radical aggression in preterm infants, Am. J. Clin. Nutr. 89 (2009) 210-215, https://doi.org/10.3945/ajcn.2008.26845.

[60] N. Nassi, V. Ponziani, M. Becatti, P. Galvan, G. Donzelli, Anti-oxidant enzymes and related elements in term and preterm newborns, Pediatr. Int. 51 (2009) 183-187, https://doi.org/10.1111/j.1442-200X.2008.02662.x.

[61] C.R. Farkouh, J.D. Merrill, P.L. Ballard, R.A. Ballard, H. Ischiropoulos, S.A. Lorch, Urinary metabolites of oxidative stress and nitric oxide in preterm and term infants, Biol. Neonate 90 (2006) 233-242, https://doi.org/10.1159/000093633.

[62] M.R. Bassiouny, H. Almarsafawy, H. Abdel-Hady, N. Nasef, T.A. Hammad, H. Aly, A randomized controlled trial on parenteral nutrition, oxidative stress, and chronic lung diseases in preterm infants, J. Pediatr. Gastroenterol. Nutr. 48 (2009) 363-369.

[63] J.K. Friel, B. Diehl-Jones, K.A. Cockell, A. Chiu, R. Rabanni, S.S. Davies, L.J. Roberts, Evidence of oxidative stress in relation to feeding type during early life in premature infants, Pediatr. Res. 69 (2011) 160-164, https://doi.org/10.1203/ PDR.0b013e3182042a07.

[64] J. Kuligowski, J. Escobar, G. Quintás, I. Lliso, I. Torres-Cuevas, A. Nuñez, E. Cubells, D. Rook, J.B. van Goudoever, M. Vento, Analysis of lipid peroxidation biomarkers in extremely low gestational age neonate urines by UPLC-MS/MS, Anal. Bioanal. Chem. 406 (2014) 4345-4356, https://doi.org/10.1007/s00216-014-7824-6.

[65] J. Kuligowski, M. Aguar, D. Rook, I. Lliso, I. Torres-Cuevas, J. Escobar, G. Quintás, M. Brugada, Á. Sánchez-Illana, J.B. van Goudoever, M. Vento, Urinary lipid peroxidation byproducts: are they relevant for predicting neonatal morbidity in preterm infants? Antioxidants Redox Signal. 23 (2015) 178-184, https://doi.org/10. 1089/ars.2015.6262.

[66] P. Chessex, C. Watson, G.W. Kaczala, T. Rouleau, M.E. Lavoie, J. Friel, J.C. Lavoie, Determinants of oxidant stress in extremely low birth weight premature infants, Free Radic. Biol. Med. 49 (2010) 1380-1386, https://doi.org/10.1016/j. freeradbiomed.2010.07.018.

[67] M. Longini, S. Perrone, P. Vezzosi, F. Proietti, B. Marzocchi, G. Buonocore, V. Fanos, R. Antonucci, E. Brunoldi, Isoprostane levels in urine of preterm newborns treated with ibuprofen for patent ductus arteriosus closure, Pediatr. Nephrol. 26 (2011) 105-109, https://doi.org/10.1007/s00467-010-1651-6.

[68] Y. Chen, G. Fantuzzi, M. Schoeny, P. Meier, A.L. Patel, High-dose human milk feedings decrease oxidative stress in premature infant, JPEN - J. Parenter. Enter. Nutr. (2018), https://doi.org/10.1002/jpen.1178 May 15.

[69] B. Weinberger, K. Watorek, R. Strauss, G. Witz, M. Hiatt, T. Hegyi, Association of lipid peroxidation with hepatocellular injury in preterm infants, Crit. Care 6 (2002) $521-525$

[70] O. Ates, H.H. Alp, I. Caner, A. Yildirim, A. Tastekin, I. Kocer, O. Baykal, Oxidative DNA damage in retinopathy of prematurity, Eur. J. Ophthalmol. 19 (2009) 80-85.

[71] I. Mohamed, W. Elremaly, T. Rouleau, J.C. Lavoie, Ascorbylperoxide contaminating parenteral nutrition is associated with bronchopulmonary dysplasia or death in extremely preterm infants, JPEN - J. Parenter. Enter. Nutr. 41 (2017) 1023-1029, https://doi.org/10.1177/0148607116643704.

[72] I. Esiaba, D.M. Angeles, M.S. Holden, J.B. Tan, Y. Asmerom, G. Gollin, D.S. Boskovic, Urinary allantoin is elevated in severe intraventricular hemorrhage in the preterm newborn, Transl. Stroke Res. 7 (2016) 97-102, https://doi.org/10 1007/s12975-015-0405-y.

[73] R.J. Madoglio, L.M. Rugolo, C.S. Kurokawa, M.P. Sá, J.C. Lyra, L.C. Antunes, Inflammatory and oxidative stress airway markers in premature newborns of hypertensive mothers, Braz. J. Med. Biol. Res. 49 (2016) e5160, https://doi.org/10. 1590/1414-431X20165160.

[74] P.V.D. Silva, J.A. Troiano, A.C.M.S. Nakamune, J.P. Pessan, C. Antoniali, Increased activity of the antioxidants systems modulate the oxidative stress in saliva of toddlers with early childhood caries, Arch. Oral Biol. 70 (2016) 62-66, https://doi. org/10.1016/j.archoralbio.2016.06.003.

[75] S. Bagci, A. Mueller, J. Reinsberg, A. Heep, P. Bartmann, A.R. Franz, Saliva as a valid alternative in monitoring melatonin concentrations in newborn infants, Early 
Hum. Dev. 85 (2009) 595-598, https://doi.org/10.1016/j.earlhumdev.2009.06. 003.

[76] A. García-Blanco, M. Vento, V. Diago, C. Cháfer-Pericás, Reference ranges for cortisol and $\alpha$-amylase in mother and newborn saliva samples at different perinatal and postnatal periods, J. Chromatogr. B Analyt. Technol. Biomed. Life Sci. 1022 (2016) 249-255, https://doi.org/10.1016/j.jchromb.2016.04.035.

[77] C. Peña-Bautista, P. Carrascosa-Marco, C. Oger, C. Vigor, J.M. Galano, T. Durand, M. Baquero, M. López-Nogueroles, M. Vento, A. García-Blanco, C. Cháfer-Pericás, Validated analytical method to determine new salivary lipid peroxidation compounds as potential neurodegenerative biomarkers, J. Pharmaceut. Biomed. Anal. 164 (2018) 742-749, https://doi.org/10.1016/j.jpba.2018.11.043.

[78] Á. Sánchez-Illana, F. Mayr, D. Cuesta-García, J.D. Piñeiro-Ramos, A. Cantarero,

M. Guardia, M. Vento, B. Lendl, G. Quintás, J. Kuligowski, On-capillary surfaceenhanced Raman spectroscopy: determination of glutathione in whole blood microsamples, Anal. Chem. 90 (2018) 9093-9100, https://doi.org/10.1021/acs. analchem.8b01492.

[79] J. Kuligowski, M.R. El-Zahry, Á. Sánchez-Illana, G. Quintás, M. Vento, B. Lendl, Surface enhanced Raman spectroscopic direct determination of low molecular weight biothiols in umbilical cord whole blood, Analyst 141 (2019) 2165-2174, https://doi.org/10.1039/c5an01865j.

[80] R. Sultana, M. Perluigi, D. Allan Butterfield, Lipid peroxidation triggers neurodegeneration: a redox proteomics view into the Alzheimer disease brain, Free Radic Biol. Med. 62 (2013) 157-169, https://doi.org/10.1016/j.freeradbiomed.2012.09. 027.

[81] M. Inayat, F. Bany-Mohammed, A. Valencia, C. Tay, J. Jacinto, J.V. Aranda, K.D. Beharry, Antioxidants and biomarkers of oxidative stress in preterm infants with symptomatic patent ductus arteriosus, Am. J. Perinatol. 32 (2015) 895-904, https://doi.org/10.1055/s-0035-1544948.

[82] S. Tokuriki, T. Okuno, G. Ohta, Y. Ohshima, Carboxyhemoglobin formation in preterm infants is related to the subsequent development of bronchopulmonary dysplasia, Dis. Markers 2015 (2015) 620921, https://doi.org/10.1155/2015/ 620921.

[83] M. Vento, M. Moro, R. Escrig, L. Arruza, G. Villar, I. Izquierdo, L.J. Roberts, A. Arduini, J.J. Escobar, J. Sastre, M.A. Asensi, Preterm resuscitation with low oxygen causes less oxidative stress, inflammation, and chronic lung disease, Pediatrics 124 (2009) e439-e449, https://doi.org/10.1542/peds.2009-0434.

[84] C.V. Lal, J. Kandasam, K. Dolma, M. Ramani, R. Kumar, L. Wilson, Z.H. Aghai, S. Barnes, J.E. Blalock, A. Gaggar, V. Bhandari, N. Ambalavanan, Early airway microbial metagenomic and metabolomic signatures are associated with development of severe bronchopulmonary dysplasia, Am. J. Physiol. Lung Cell Mol. Physiol. 315 (2018) L810-L815, https://doi.org/10.1152/ajplung.00085.2018.

[85] I.H. Buss, R. Senthilmohan, B.A. Darlow, N. Mogridge, A.J. Kettle,

C.C. Winterbourn, 3-Chlorotyrosine as a marker of protein damage by myeloperoxidase in tracheal aspirates from preterm infants: association with adverse respiratory outcome, Pediatr. Res. 53 (2003) 455-462, https://doi.org/10.1203/01. PDR.0000050655.25689.CE.

[86] E. Kato, S. Ibara, K. Kumazawa, Y. Maruyama, T. Tokuhisa, T. Matsui, R. Shimono, Y. Maede, H. Minakami, Effects of supplemental oxygen on urinary 8-hydroxy-2'deoxyguanosine levels in extremely low birth weight infants, Free Radic. Res. 48 (2014) 1285-1290, https://doi.org/10.3109/10715762.2014.951841.

[87] T. Matsubasa, T. Uchino, S. Karashima, Y. Kondo, K. Maruyama, M. Tanimura, F. Endo, Oxidative stress in very low birth weight infants as measured by urinary 8 OHdG, Free Radic. Res. 36 (2002) 189-193.

[88] H. Tsukahara, M.Z. Jiang, N. Ohta, S. Sato, S. Tamura, M. Hiraoka, M. Maeda, M. Mayumi, Oxidative stress in neonates: evaluation using specific biomarkers, Life Sci. 75 (2004) 933-938, https://doi.org/10.1016/j.lfs.2004.01.025.

[89] G. Fusch, S. Mitra, H. Topp, A. Agarwal, S.H. Yiu, J. Bruhs, N. Rochow, A. Lange, M. Heckmann, C. Fusch, Source and quality of enteral nutrition influences oxidative stress in preterm infants: a prospective cohort study, JPEN - J. Parenter. Enter. Nutr. (2018), https://doi.org/10.1002/jpen.1156 Mar 30.

[90] O. Korchazhkina, E. Jones, M. Czauderna, S.A. Spencer, Effects of exclusive formula or breast milk feeding on oxidative stress in healthy preterm infants, Arch. Dis. Child. 91 (2006) 327-329, https://doi.org/10.1136/adc.2005.084798.

[91] H. Shoji, N. Ikeda, M. Hosozawa, N. Ohkawa, N. Matsunaga, H. Suganuma, K. Hisata, K. Tanaka, T. Shimizu, Oxidative stress early in infancy and neurodevelopmental outcome in very low-birthweight infants, Pediatr. Int. 56 (2014) 709-713, https://doi.org/10.1111/ped.12332. 